Errata

\title{
Lack of effect of exendin-4 and glucagon-like peptide-1-(7,36)-amide on insulin action in non-diabetic humans
}

\author{
A. Vella ${ }^{2}$, P. Shah ${ }^{2}$, A. S. Reed ${ }^{2}$, A. S. Adkins ${ }^{2}$, R. Basu' ${ }^{2}$, R. A. Rizza ${ }^{1,2}$ \\ ${ }^{1}$ Mayo Clinic and Foundation, Rochester, USA \\ ${ }_{2}^{2}$ Department of Internal Medicine, Division of Endocrinology, Metabolism and Nutrition, Mayo Clinic and Foundation, Rochester, USA
}

\section{Diabetologia (2002) 45:1410-1415}

The authors identified several errors after their paper had been printed:

1. C-peptide values were inadvertently converted to $\mathrm{nmol} / \mathrm{l}$ from $\mathrm{ng} / \mathrm{ml}$ by multiplying by 0.331 twice. Correct values require division of reported values by 0.331 .

2. Fig. 2: the Y-axis for growth hormone should be labelled as $\mu \mathrm{g} / \mathrm{l}$.

3. The mean growth hormone concentration at $0 \mathrm{~min}$ on the saline study day was incorrectly plotted. The correct value was $2.34 \mu \mathrm{g} / \mathrm{l}+/-1.64$.

4. Fig. 2: the Y-axis for cortisol should be labelled as $\mathrm{nmol} / \mathrm{l}$
Published online: 31 October 2003

(C) Springer-Verlag 2003

DOI 10.1007/s00125-003-1250-1

The online version of the original article can be found at http://dx.doi.org/10.1007/s00125-002-0924-4

Corresponding author: R. A. Rizza, Mayo Clinic and Foundation, 200 1st Street SW, Rm 5-194 Joseph, Rochester, MN 55905, USA

E-mail: rizza.robert@mayo.edu

\section{Trends in hypertension management in Type I diabetes across Europe, 1989/1990 - 1997/1999}

\author{
S. S. Soedamah-Muthu ${ }^{1,2}$, H. M. Colhoun ${ }^{2}$, H. Abrahamian ${ }^{3}$, N. N. Chan ${ }^{2}$, R. Mangili ${ }^{4}$, G. P. Reboldi ${ }^{5}$, \\ J. H. Fuller ${ }^{2}$, the EURODIAB Prospective Complications Study Group \\ ${ }^{1}$ EURODIAB, Department of Epidemiology and Public-Health, Royal Free and University College London Medical School, London, UK \\ 2 Department of Epidemiology and Public-Health, Royal Free and University College London Medical School, London, UK \\ ${ }^{3}$ Medical department, Hospital Vienna Lainz, Vienna, Austria \\ ${ }^{4}$ Divisions di Medicina, Instituto Scientifico San Raffaele, Milan, Italy \\ ${ }^{5}$ Dipartimento di Medicina Interna e Scienze, Endocrine e Metaboliche, Perugia, Italy
}

\section{Diabetologia (2002) 45:1362-1371}

In the footnote of Table 2, the last item in this table "Controlled" should be indicated with the letter "f", meaning "Proportion of treated hypertensives".
Published online: 2 October 2003

C) Springer-Verlag 2003

DOI 10.1007/s00125-003-1210-9

The online version of the original article can be found at http://dx.doi.org/10.1007/s00125-002-0914-6

Corresponding author: S. S. Soedamah-Muthu, EURODIAB, Department of Epidemiology and Public-Health, Royal Free and University College London Medical School, 1-19 Torrington Place, London, WC1E 6BT, UK,

E-mail: sabita@public-health.ucl.ac.uk 